INTERNATIONAL JOURNAL OF ENVIRONMIENT

Volume-9, Issue-2, 2019/20

Received: 28 April 2020
Revised: 29 September 2020
ISSN 2091-2854

Accepted: 2 October 2020

\title{
VULNERABILITY ASSESSMENT OF PEOPLES EXPOSED TO LANDSLIDES IN \\ PANCHASE OF NEPAL USING ANALYTICAL HIERARCHY PROCESS
}

\author{
Padam Bahadur Budha ${ }^{1,2 *(D)}$, Pawan Rai ${ }^{2,3}$, Prem Katel ${ }^{2}$ (D), Anu Khadka ${ }^{4}$ (D) \\ ${ }^{1}$ Nepal Environmental Resources Organization, Kathmandu, Nepal \\ ${ }^{2}$ Xavier International College, Department of Environmental Science, Kathmandu, Nepal \\ ${ }^{3}$ Goldengate International College, Environmental Science Program, Kathmandu, Nepal \\ ${ }^{4}$ Southern Illinois University Edwardsville, Department of Environmental Sciences, Illinois, USA \\ * Corresponding author:padambudha88@gmail.com
}

\begin{abstract}
The occurrence of landslides in mountainous areas of Nepal is recurrent phenomena and this can be disastrous if occurred within human settlements. Proper research is required to manage and reduce the risks of the disaster in places where landslides had occurred frequently. In risk assessment estimation of vulnerability is one major component. This research was aimed to generate information on the vulnerability of people in the Panchase area of central Nepal. The method of analytical hierarchy process was used to define the weightage to be assigned for 4 factors and 26 indicators used in the research. 377 households were surveyed with a questionnaire designed to collect information on those indicators. The households sampled for the survey were made sure that they were near or around the landslide affected area. The response for each indicator was converted into scores which when summed up yielded the vulnerability score. This score for each household was used to categorize households into five levels of vulnerability from very low, low, moderate, high, to very high. The numbers of households in each category were 16, 92, 191, 75, and 3 respectively. Environmental and economic indicators were inflicting higher vulnerability in this research location. Remoteness and lesser number of facilities and/or services, lower numbers of governmental offices, absence of banking and financial institutions, lesser preferences for insurances and savings, degraded natural water sources were major determinants of higher vulnerability in Panchase. These indicators should be prioritized during disaster risk management in Panchase.

Keywords: Indicator assessment, landslide hazards, risk reduction, social vulnerability.
\end{abstract}

DOI: http://dx.doi.org/10.3126/ije.v9i2.32535

Copyright @2020 IJE

This work is licensed under a CC BY-NC which permits use, distribution and reproduction in any medium provided the original work is properly cited and is not for commercial purpose 


\section{Introduction}

The vulnerability can be taken as a state of a system that reflects how the system is prone to the harmful effects of hazards. It is defined as the potential for loss to the elements at risk caused by the occurrence of a hazard and depends on multiple aspects arising from physical, social, economic, and environmental factors, which are interacting in space and time (Ciurean et al., 2013). Vulnerability is frequently used in the literature of risks, hazards, and disaster and has greater potential in the areas of global changes, environmental perturbations, and developmental studies (Cutter et al., 2003). It is one important component of risk estimation in disaster risk reduction. The knowhow of vulnerability can be useful in all phases of the disaster cycle. For a mountainous country like Nepal, it is vital to estimate the vulnerability as many settlements are exposed to many hazards. Information on vulnerability for a place would be used in designing the coping mechanisms during the development of mitigation plans for that particular area. The knowledge developed would support in identification and prioritization needy and more vulnerable populations with higher exposure towards disasters.

Frequently occurring landslides can be taken as a common hazard in mountainous areas of Nepal. Numerous landslides can be observed in hilly and mountain regions of Nepal. The prime reason may be the continuous mountain building process in the Himalayas. Besides, higher relief of mountains in the Himalaya makes them landslide prone in the times of high-intensity rainfall and earthquakes (Kayastha et al., 2013). The casualties due to such landslides are also higher in the mountains of Nepal. About 72 humans were reported dead due to a single day landslide event that hit the Seti River on May 5, 2012 (Gurung et al., 2015). Besides, there are annual incidents of landslides and floods in Kaski and neighboring districts. The frequent occurrence of landslides around Panchase is deteriorating the natural resources and the debris produced is carried by rivers giving rise to sedimentation and loss of aquatic biodiversity. Some landslides had impacted the settlements, disrupted transportation, and damaged some houses and agricultural land also. It seems that people are annually facing losses from landslides which in turn is increasing their vulnerability. Here estimation of vulnerability seems important in preparing mitigation plans and strategies and to prioritize settlements that are highly exposed to landslides.

The researches on vulnerability in Nepal started in the last decade only and these were studies conducted in the country. Some studies have done vulnerability estimate at a national scale like that of $\mathrm{KC}$ (2013) and Aksha et al. (2019) but their results vary at a local scale as observed by Sujakhu et al. (2019) and Budha et al. (2020a). The selection of indicators is a key consideration in such assessments which varies at both local and national scale, where data quality can be coarser for national-level studies. With the findings of the national 
scale, it will be a tough task to manage disasters at the local level. Considering this, it became vital to conduct vulnerability at a local scale for areas severely affected by hazards. The major objective of this research is to estimate the vulnerability of peoples in the landslide-hit Panchase area. This research was aimed to produce spatial information on household vulnerability and determine the factors that were inducing higher vulnerability.

\section{Materials and Methods}

\subsection{Study area}

The experimental site for this research was Panchase Mountain Ecological Region, Panchase hereafter. The name 'Panchase' had the meaning as a meeting point of five mountains. Figure 1 showed the location of this study site in Nepal where the peak of the Panchase Mountain is shown by a triangle. It occupied partial area of Kaski, Parbat, and Syangja districts and measured $278.324 \mathrm{~km}^{2}$. The area included parts of six local units, namely Pokhara Metropolitan City (MC), Annapuma Rural Municipality (RMP), Modi RMP, Kushma Municipality (MP), Aandhikhola RMP, and Phedikhola RMP, as depicted in Figure 1.

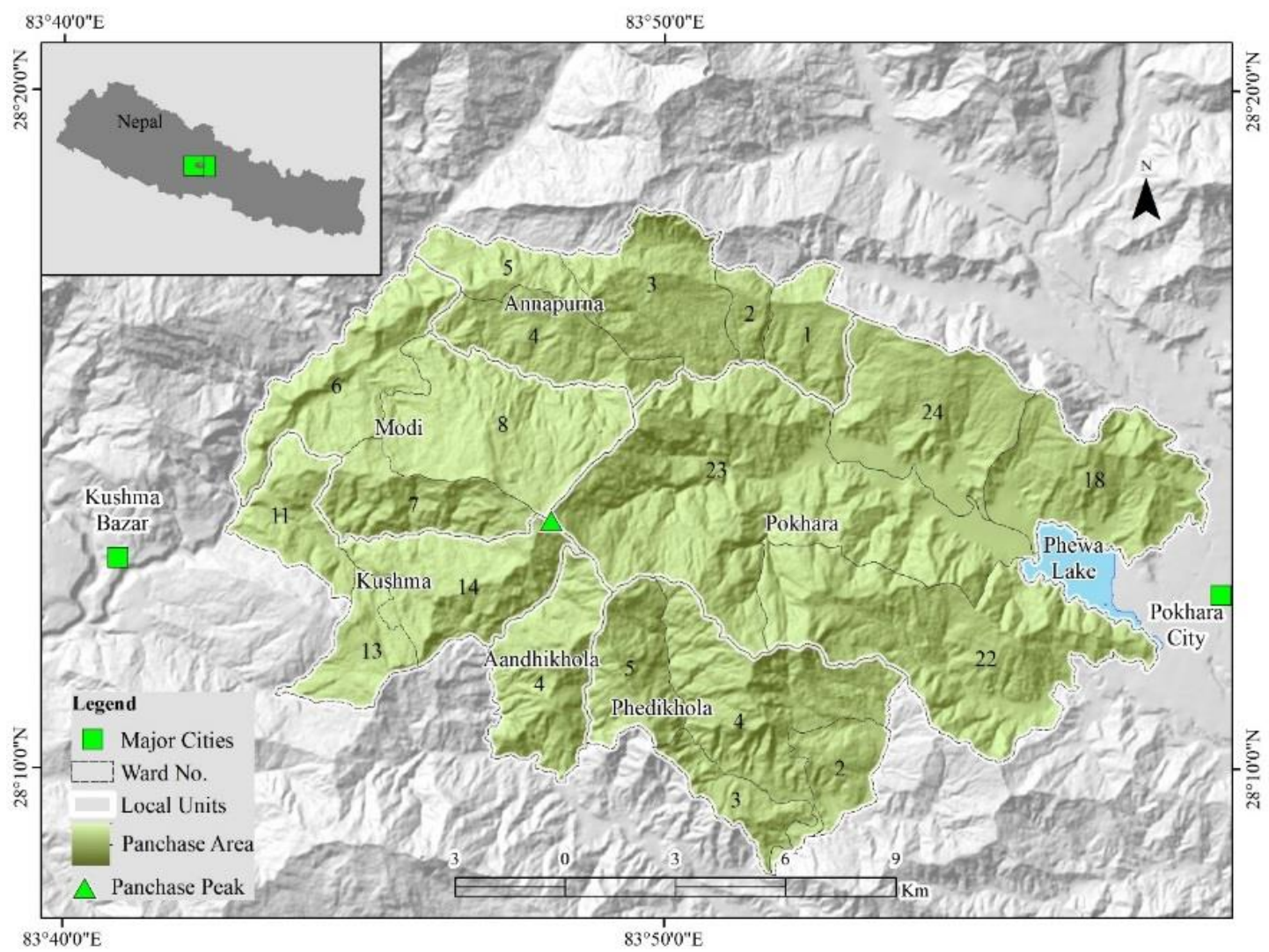

Figure 1: Panchase area showing local units and ward numbers (inset; its location in central Nepal). 
The lowest point of elevation in the study area was $715 \mathrm{~m}$ and the highest elevation being Peak of Panchase Mountain was $2504 \mathrm{~m}$. The peak is surrounded by dense forests. At lower altitudes, the lands are cultivated and settlements can be found. Major forests that can be found in Panchase were Alnus-Schima, CastanopsisPinus, Daphniphyllum, and Rhododendron-Quercus forests (Phuyal et al., 2015). These forests represented lower subtropical, upper subtropical, and lower temperate bioclimatic zones. The meteorological records of the Department of Hydrology and Meteorology (DHM) of GoN showed the lowest average temperature of $5.3^{\circ} \mathrm{C}$ and the highest average temperature of $29^{\circ} \mathrm{C}$ with an annual average rainfall of $3882 \mathrm{~mm}$ (DHM, 2017). The area receives the highest amount of average rainfall in Nepal.

\subsection{Data Sources}

The data used in this study were composed of both primary and secondary sources. Primary sources of data were information obtained from the questionnaire survey and data produced from satellite imageries. Some of the secondary data on population and households were obtained from the Central Bureau of Statistics (CBS), and digital data of topographic sheets from the Department of Survey.

Landslide inventory includes an enumeration of location, date of occurrence, and type of movement (Guzzetti, 2005) of landslide incidents which can be extracted from satellite imageries, topographic sheets, or field surveys. The inventory of landslides was generated primarily from Google Earth and updated after the fieldwork. In Google Earth images the scars of landslides were digitized and analyzed in Geographic Information System (GIS) environment. In the field study data regarding the surrounding conditions, impacted areas, and elements were being recorded.

\subsection{Research Process}

The vulnerability assessment in this research followed the indicator-based approach (Budha et al., 2020a) which consisted of stages such as; indicator selection, weightage and scoring, questionnaire development and data collection, data analysis, and vulnerability estimation with mapping. This can be further clarified by the flow chart for the research process shown in Figure 2 and the description of each stage can be found in the following sections. 


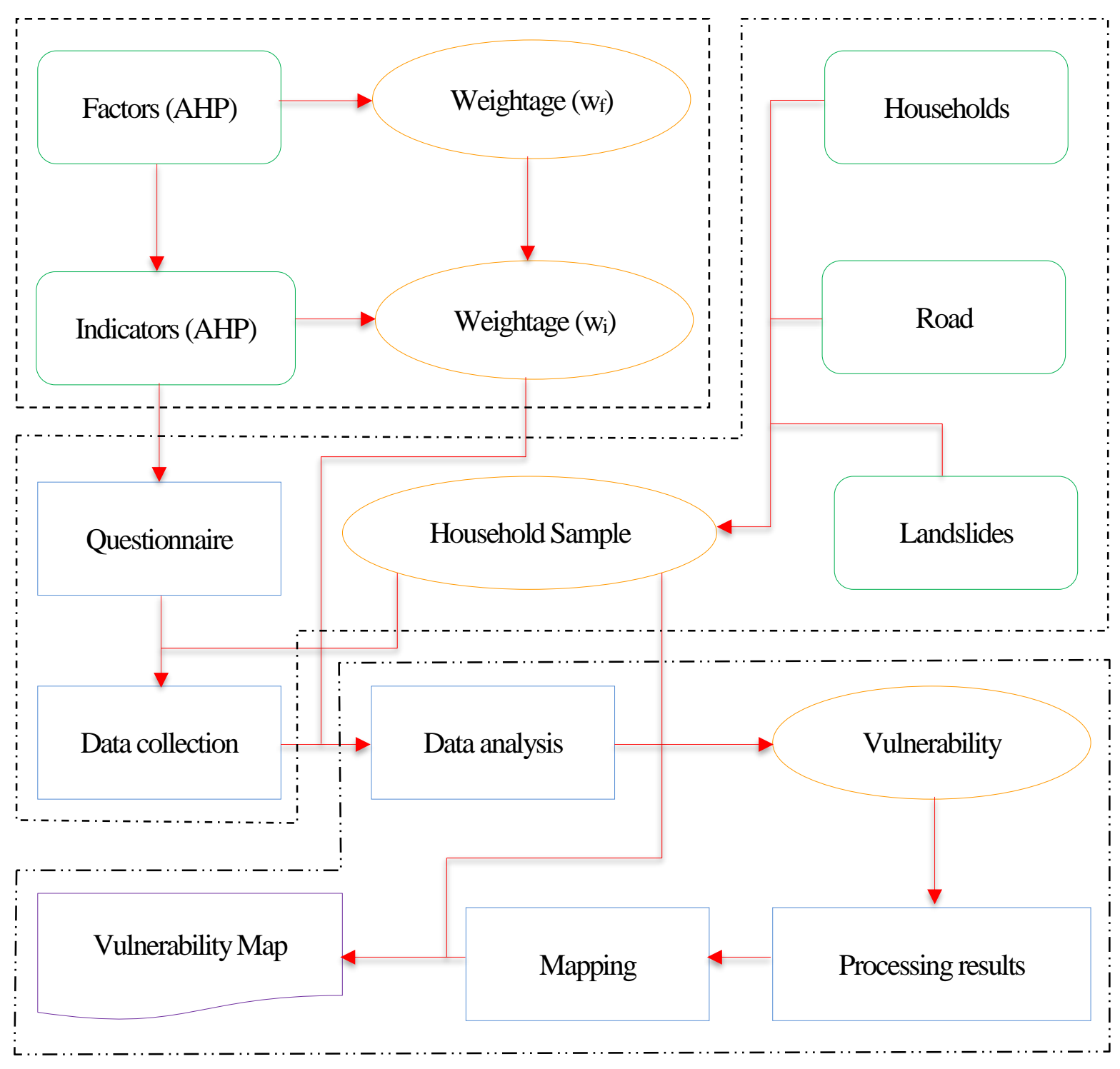

Figure 2: Flow chart for the process of vulnerability estimation

\subsubsection{Indicator Selection}

The selection of indicators and their weightage estimation is the first part of the vulnerability assessment as shown by the first box (dashed boundary) in Figure 2. Vulnerability depends upon social, physical, economic, and environmental factors, and their sub-factors were taken as indicators. These indicators were selected in such a way that they represent the maximum characteristics of the area being studied so that sufficient information can be obtained from them. Based on the literature and conditions of the study area 26 indicators were selected as listed in Table 1.

The indicators of social factors include population size of households, economically active members, and the highest level of education among family members (Cutter et al., 2003; KC, 2013). Participation in social works, availability of governmental services, and frequency works from non-governmental organizations also 
have a significant influence on the social factor of vulnerability (Madhuri et al., 2014; Dixit et al., 2015). On the other hand, indicators of physical factors were the house structure, road condition, school types, distance to health posts, and drinking water supply schemes (Ebert and Kerle, 2008; Dixit et al., 2015). High quality of houses will decrease the vulnerability of the exposed elements. Similarly, the availability of more facilities helps in the reduction of vulnerability. Some facilities of electricity and communications can also be incorporated into physical factors of vulnerability.

Table 1: List of indicators with their symbols inside brackets

\begin{tabular}{|l|l|}
\hline Social Indicators & Physical Indicators \\
\hline Family size (SO1) & Roads types (PY1) \\
\hline Dependent age group (SO2) & Building types (PY2) \\
\hline People with disabilities (SO3) & Schools level (PY3) \\
\hline Highest education (SO4) & Distance to health post (PY4) \\
\hline Participation in social activities (SO5) & Electricity sources (PY5) \\
\hline Governmental Services (SO6) & Water supply (PY6) \\
\hline Non-Governmental services (SO7) & Communication facilities (PY7) \\
\hline Economic Indicators & Environmental Indicators \\
\hline Banking facilities (EC1) & Lakes and Ponds (EN1) \\
\hline Insurance facilities (EC2) & Protected Forest (EN2) \\
\hline Employment options (EC3) & Land use land cover (EN3) \\
\hline Cropping pattern (EC4) & Faunal diversity (EN4) \\
\hline Livestock diversity (EC5) & Agricultural Lands (EN5) \\
\hline Monthly expenditure (EC6) & \\
\hline Savings (EC7) & \\
\hline
\end{tabular}

In the case of the economic factor of vulnerability different income opportunities were studied. This includes a variety of employments, diversity in crops as well as livestock (Tesso et al., 2012; Madhuri et al., 2014). Here the direct and indirect impact on economic opportunities from landslides was an important parameter to consider as it can alter the level of vulnerability of the same things based on the impacts. Other indicators were the availability of banking and insurance facilities where the savings or insurance policy adopted were key measures (Dixit et al., 2015) considered. Besides, monthly expenditure gave an idea of family income.

Finally, in environmental factors of vulnerability forest coverage and status along with the availability of important flora and fauna available were recorded. Patterns of agriculture and the presence of ponds/lakes nearby were also assessed (Hahn et al., 2009; Tesso et al., 2012). The lower the forest area higher will be the impact of landslides and hence higher will be the vulnerability. 


\subsubsection{Weightage estimation}

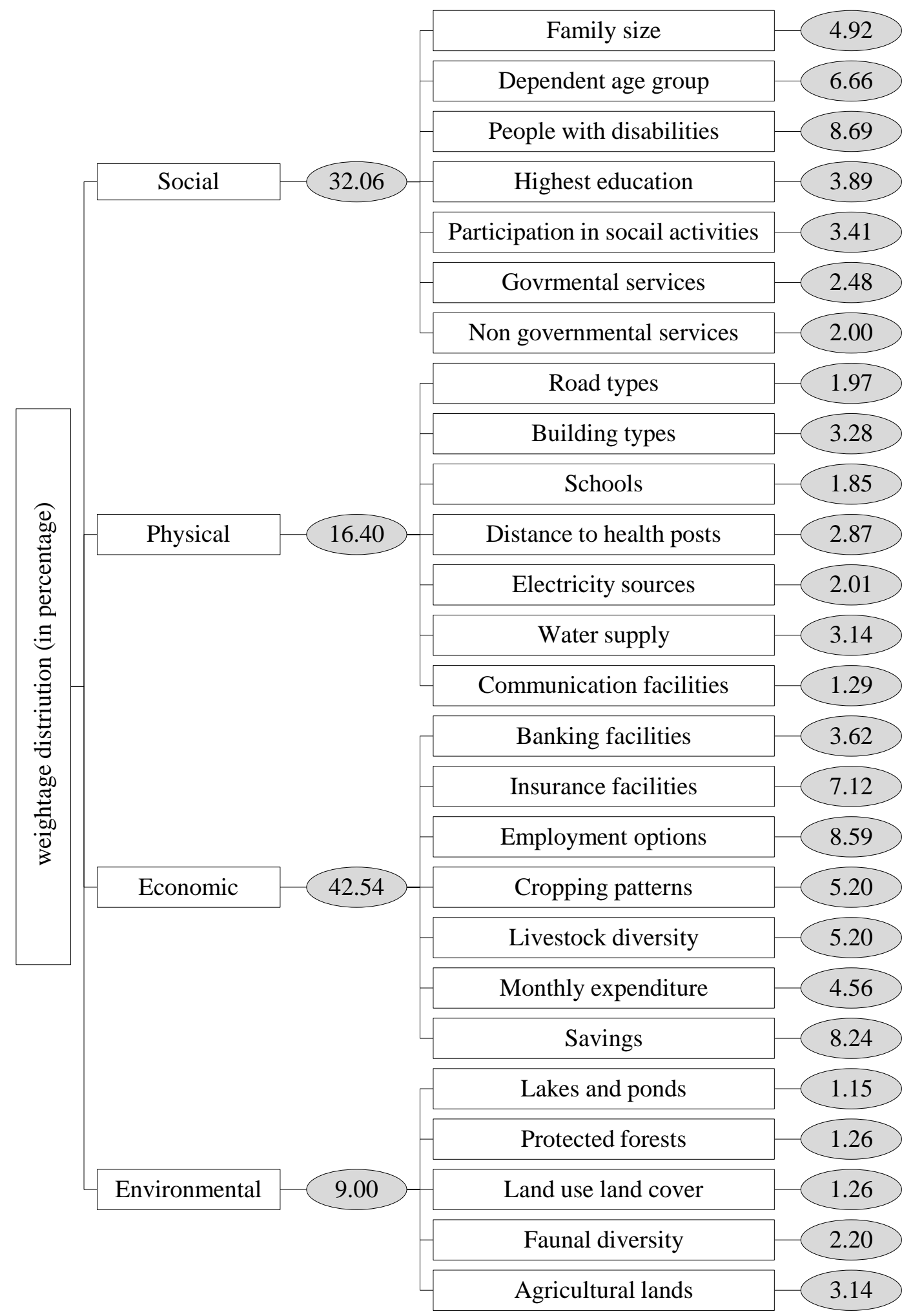

Figure 3: Weightage of factors and indicators, derived from AHP, in percentage 
After the selection of indicators, the determination of weightage to be assigned for each of them was the next step. Here, the analytical hierarchical process (AHP) was used as the determiner of the weightage for each factor and indicator. This method of AHP was introduced by Saaty (1990) to aid the decision-maker in priority setting and coming to a conclusion. AHP is particularly helpful when a decision is to be made from multiple criteria as it reduces the complexity of decision making by pairwise comparison of each criterion with others to synthesize the outcome. Here, the consistency of the criteria being compared was checked to ensure that the outcomes are non-biased. The AHP supports both qualitative and quantitative aspects of decision making by making comparisons and weightage development respectively.

This method of AHP had been used in a multi-criteria decision-making process where an occurrence of an event is dependent upon numerous factors. As disasters are the outcome of different factors, AHP had been widely used to develop weightage to be given to each factor. The AHP method was used for landslide susceptibility analysis (Bhatta et al., 2013; Das and Raja, 2015), vulnerability threat assessment (Yue and Zhang, 2014), flood vulnerability assessment (de Brito et al., 2018), and urban vulnerability assessment for earthquake crisis management (Rezaei and Tahsili, 2018). Here, AHP (Saaty, 1990; 2008) was used to define the weightage of each factor and individual indicators in vulnerability estimation. The weight value shown in Figure 3 for major factors and each indicator were estimated by using AHP. The contingency table for AHP for factors and indicators is provided in Appendix as Table A1 and Table A2.

Here, the AHP produced weight value for each factor and each indicator in a range from zero to one. These values were converted into percentages by using Equation 1 and Equation 2 .

$\begin{array}{ll}\% w_{f}=w_{f} * 100 & \text { Equation } 1\end{array}$

Where, $\% \mathrm{w}_{\mathrm{f}}$ is the weightage of a factor in percentages,

$\mathrm{W}_{\mathrm{f}}$ is the weightage of each factor produced by AHP.

$\begin{array}{ll}\% w_{i}=w_{i} * \% w_{f} & \text { Equation } 2\end{array}$

Where, $\% \mathrm{w}_{\mathrm{i}}$ is the weight of each indicator in percentages,

$\mathrm{W}_{\mathrm{i}}$ is the weightage of each indicator produced by AHP.

\subsubsection{Data collection and analysis}

The second part of the vulnerability assessment consisted data collection stage which is shown in Figure 2 (inside dash-dotted boundary). A questionnaire was developed, based on indicators, to collect information on the status of households located in Panchase. The questionnaire was designed in such a way that the information obtained could be analyzed quantitatively. This is provided in Table A3 of the Appendix. The location of households was produced from the digitization of topographic maps. Newer houses were digitized 
from Google Earth. Similarly, road data was obtained from open street maps. So these buildings and roads were identified as elements at risk which were shown in Figure 4.

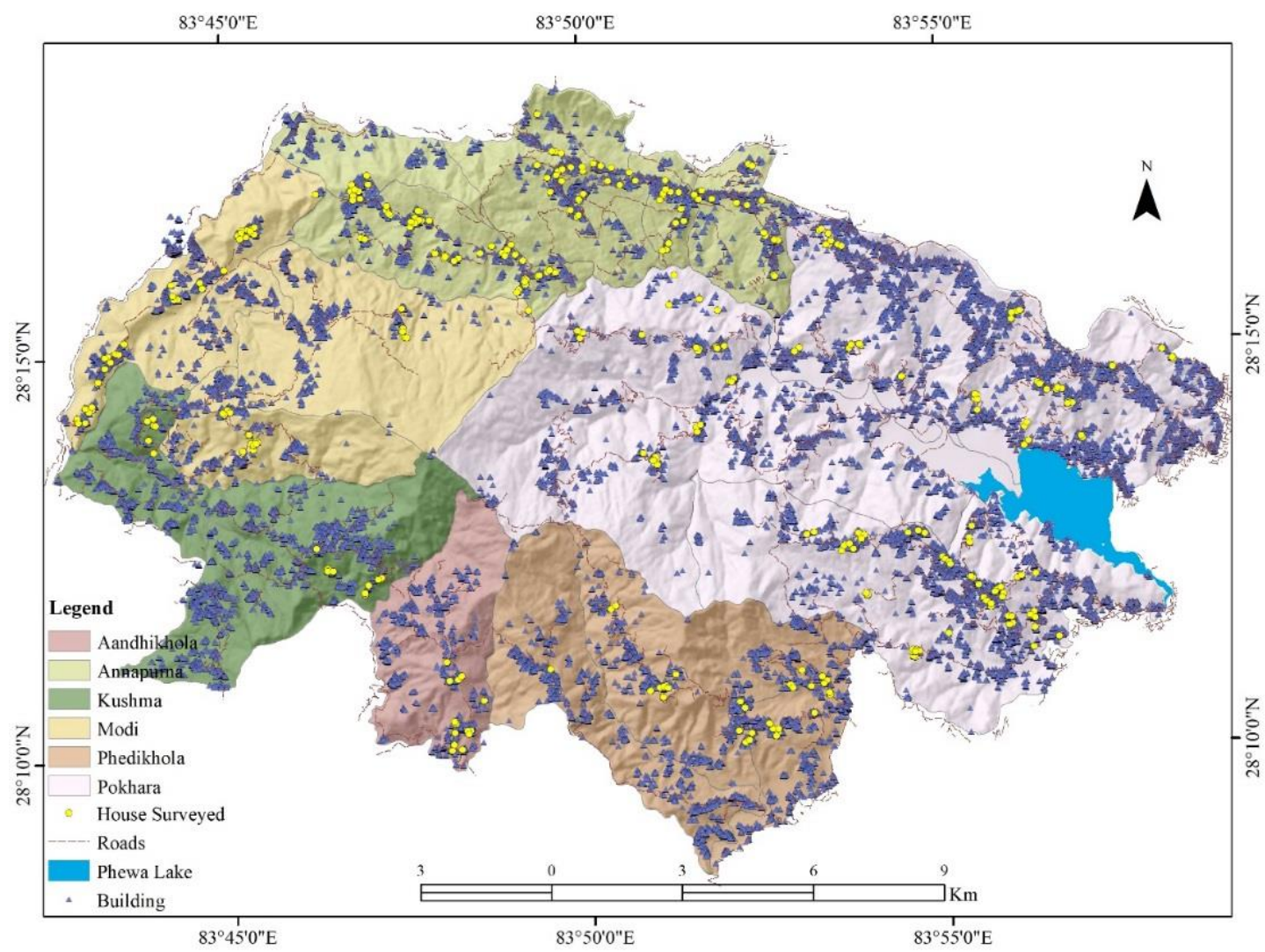

Figure 4: Distribution of households and roads along with sampled households for the survey

There were 18,320 households in the research area. This household data was used to determine the sample size of households required for the survey. 377 was the sample size of households obtained from a statistical method (Krejcie and Morgan, 1970) with a 95\% confidence interval and a 5\% margin. A stratified random process was used to select those 377 households. During the selection, a constraint factor of $1 \mathrm{~km}$ buffer of landslides was used in the process to make ensure the household surveyed are under high risk of landslides. After the selection of households and developing the questionnaire, a field survey was done for data collection.

\subsubsection{Vulnerability estimation and mapping}

The final part of a vulnerability assessment is data analysis and mapping of the results depicted by the last box (dash-dot-dotted boundary). The vulnerability of a household surveyed would depend upon the response obtained for each of the indicator-based questions. There were four categories for a response of each question resembling vulnerability conditions from very low, moderately low, moderately high to very high. The data obtained for each questionnaire would resemble any one of these categories for which it would obtain certain parentage of respective weights. If the response revealed the highest vulnerability category it would obtain full 
weightage of $\mathrm{w}_{\mathrm{i}}$. Similarly, responses with moderately high category would obtain $60 \%$ of $\mathrm{w}_{\mathrm{i}}$. Again, the response if revealedmoderately low category would obtain $30 \%$ and if it showed a very low category would obtain only $10 \%$ of $\mathrm{w}_{\mathrm{i}}$. Thus, the real weight value obtained for the indicator as per survey response is part of the weight of indicator obtained from the AHP process. This real weight of each indicator can be taken as vulnerability scores $\left(\mathrm{V}_{\mathrm{i}}\right)$

Finally, the vulnerability scores for each indicator $\left(V_{i}\right)$ of a surveyed household were summed to obtain the total vulnerability score $\left(\mathrm{V}_{\mathrm{t}}\right)$ that showed the vulnerability status for that individual house. This additive approach, shown in Equation 3, to estimate vulnerability was used by Chakraborty and Joshi (2016).

$V_{t}=\sum_{i}^{n=26} V_{i} \quad$ Equation 3

The sum of vulnerability scores $\left(V_{t}\right)$ for a house will result in a two-digit decimal number which was standardized from 0 to 1 to compare with other results. The values of those indicators were normalized using minimum-maximum relation, given in Equation 4, that was used by Briguglio et al. (2009):

$V=\frac{V_{t}-V_{t \min }}{V_{t \max }-V_{t \min }} \quad$ Equation 4

Where,

$\mathrm{V}$ is the normalized vulnerability value of a household

$\mathrm{V}_{\mathrm{tmin}}$ is the lowest vulnerability score in the range of $\mathrm{V}_{\mathrm{t}}$ for household

$\mathrm{V}_{\mathrm{tmax}}$ is the highest vulnerability score in the range of $\mathrm{V}_{\mathrm{t}}$ for household

Individual houses based on normalized vulnerability were classified into appropriate classes of five divisions as depicted in Table 2. Then, the numerical values of each household were interpolated to obtain the distribution of vulnerability in the study area.

Table 2: Vulnerability Classes based on normalized scores

\begin{tabular}{|l|l|}
\hline $\begin{array}{l}\text { Range of normalized vulnerability } \\
\text { score (w) }\end{array}$ & Vulnerability Class \\
\hline $0-0.2$ & Very Low Vulnerable \\
\hline $0.2-0.4$ & Low Vulnerable \\
\hline $0.4-0.6$ & Moderate \\
\hline $0.6-0.8$ & High Vulnerable \\
\hline $0.8-1$ & Very High Vulnerable \\
\hline
\end{tabular}

Thus, obtained vulnerability values were mapped to locate the vulnerability of a particular household, and their distribution. The derived map was also classified into five classes of vulnerability, according to criteria mentioned in Table 2, to depict the spatial coverage of vulnerability. 


\section{Results and Discussion}

\subsection{Landslide Inventory and Distribution}

There were 556 landslides marked from Google Earth and field visits in this area measuring $1.51 \mathrm{~km}^{2}$ (Budha et al., 2020b) making landslide density of almost 2 per $\mathrm{km}^{2}$. Figure 5 represents the landslide inventory map of Panchase laid over the local MP/RMP. In past researches of landslide hazard zonation, the landslide density was found to be 0.44 per $\mathrm{km}^{2}$ (Basnet et al., 2006) in the Phewa watershed and 0.571 per km² (Bhatt et al., 2013) in the Rupa watershed. These landslide densities were lower than that was found in the entire Panchase region. As all the studies were carried in similar region results indicate that landslide incidents were increased since those studies were done.

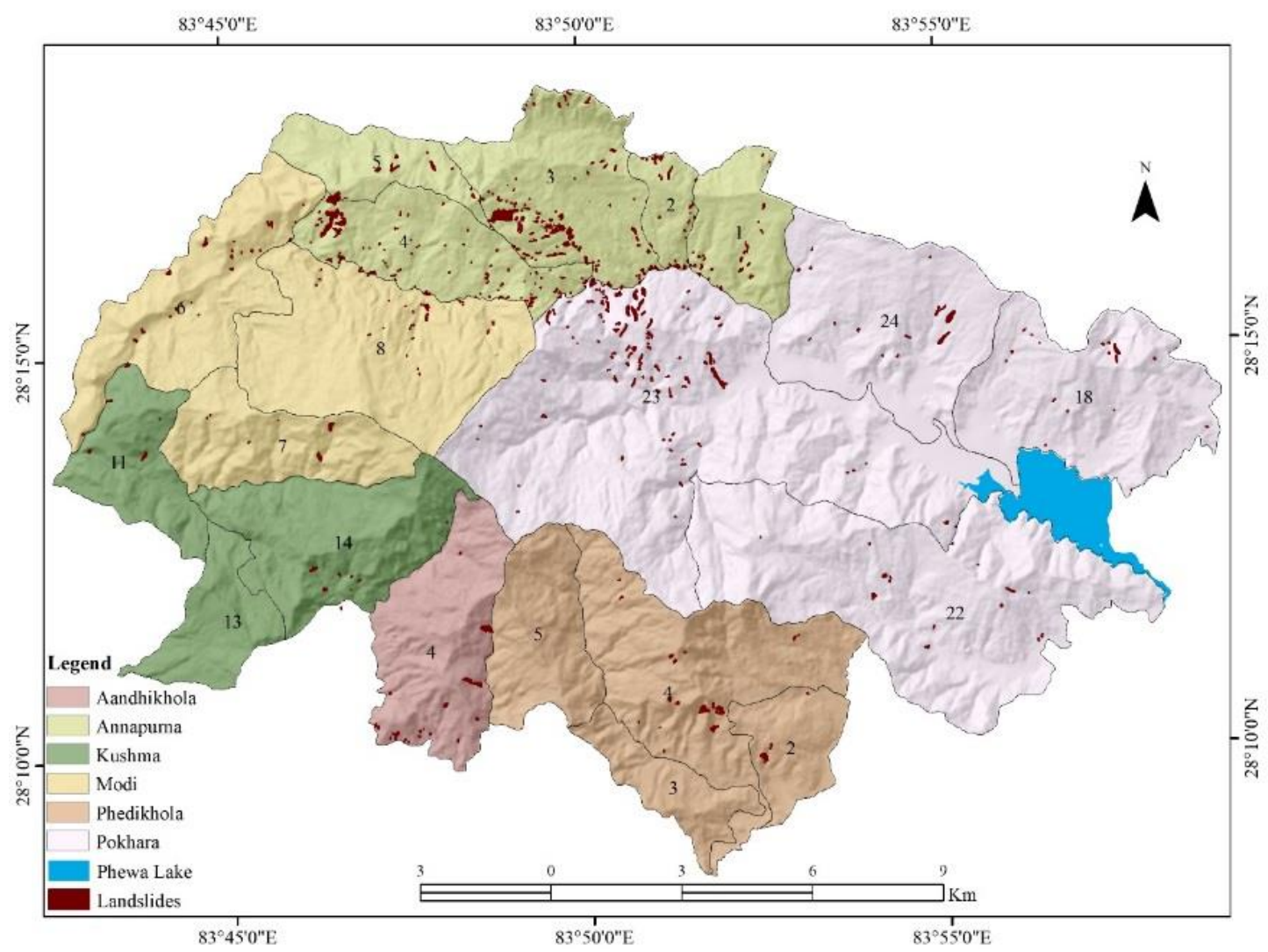

Figure 5: Landslides inventoried and their distribution in local municipalities and rural municipalities

The highest number of landslides, 281, were observed in Annapurna RMP, and least, 14, in Kushma MP. In Pokhara MC there were 150 landslides. Significant numbers of landslides were located from Modi RMP, Aandhikhola RMP, and Phedikhola RMP as 58, 24, and 29 respectively. So it seemed almost 50\% of landslides were from Annapurna RMP. Landslides were not observed at the Panchase peak where there is 
undisturbed dense forest. Similarly, the lake area nearby Pokhara is also devoid of landslides due to flat terrain. Further ward-wise distribution of landslides can be obtained from Budha et al. (2020b).

\subsection{Household Vulnerability and Distribution}

The spatial distribution of vulnerability is shown in Figure 6. The map is produced from the interpolation of standard vulnerability scores for each surveyed household. Out of 377 households studied $50.66 \%$ showed moderate vulnerability. 191 households occupy this category. The standard score of 75 households ranged from 0.6 to 0.8 making them highly vulnerable. Only 3 households were observed in a very high vulnerable class and those were from Modi RMP, Annapurna RMP, and Pokhara MC. There were 16 and 92 households in the very low and low category of vulnerability classes respectively.

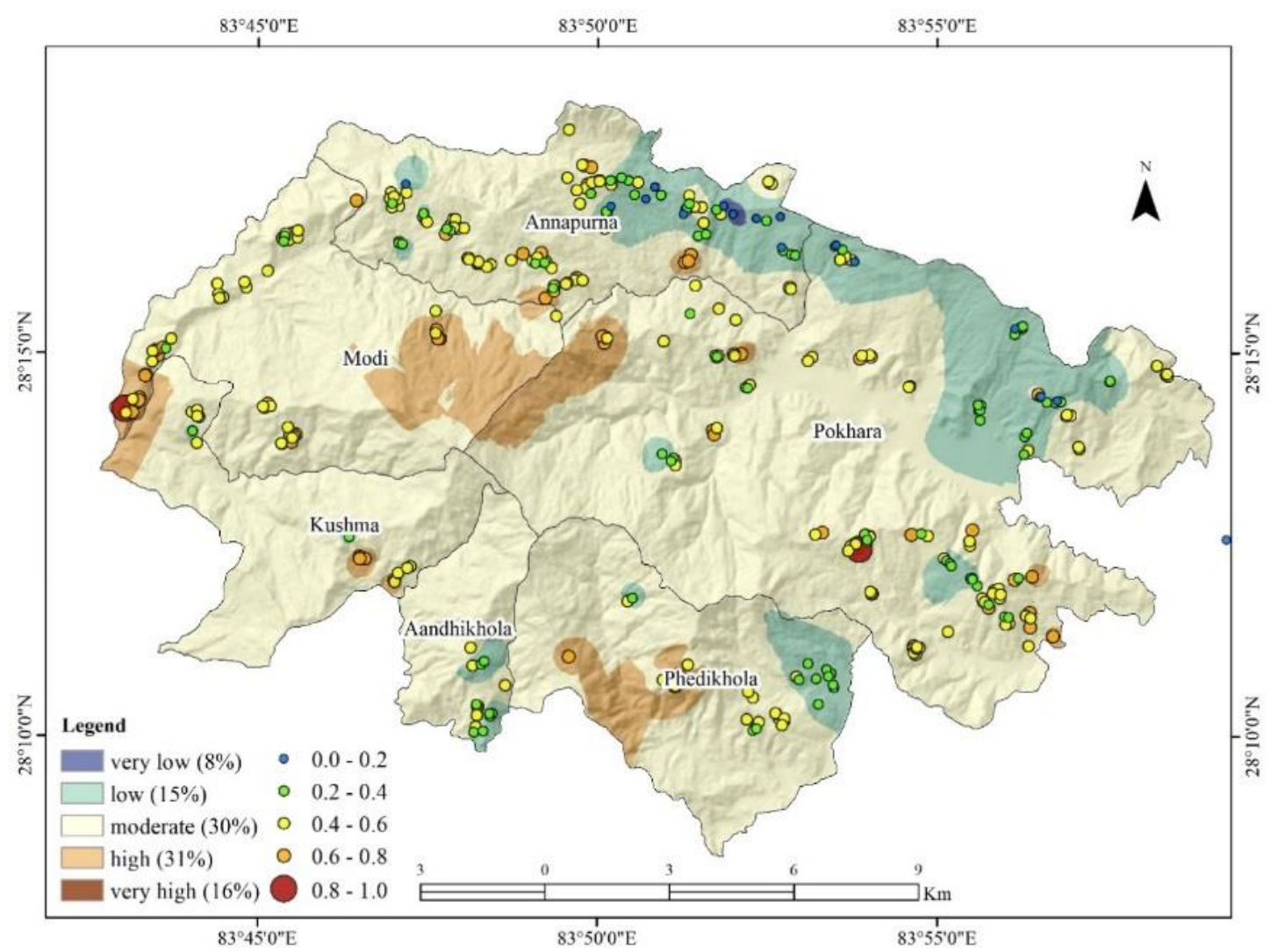

Figure 6: Household distribution based on their vulnerability scores with municipalities and ruralmunicipalities

In Figure 6 we can see that the lower category of vulnerability is spread over the northern part of Pokhara MC and the eastern part of Annapurna RMP. Similarly, higher categories of vulnerability are located eastern part of Modi RMP and south-western part of Phedikhola RMP. Looking at Figure 6, it appeared the area occupied by the high and very high vulnerability is $46 \%$ of the total area of Panchase which is $131.04 \mathrm{~km}^{2}$. Low and 
very low categories occupied about $23 \%$ of the total area which becomes $64.38 \mathrm{Km}^{2}$. The remaining area of Panchase lied in a moderate vulnerability zone.

Houses with very low categories of vulnerability were located along the highway and had easy access to transportation to the nearest markets. Besides, there were ample facilities for health and education near the areas of those households. On the contrary, the higher vulnerable households were located in areas of higher reliefs where transportation facilities were infrequent and it was time-consuming to reach the towns. Also, other health and education facilities were very less in the vicinity and if available are distant to reach. This fact indicated the increase in vulnerability of peoples.

\subsection{Indicators Influence on Vulnerability}

The vulnerability of the household was determined by summing the individual vulnerability score obtained by each indicator. Since this score was a certain percentage of the weightage of a particular indicator it became necessary to find out which indicators scored higher values. Higher scores obtained by each indicator pointed out their greater influence in making households more vulnerable. Thus, the higher the obtained score higher will be the vulnerability. Now we took averages, for 377 households, of the scores obtained for a particular indicator to determine their influence on vulnerability.

Table 3: Vulnerability scores obtained for social indicators

\begin{tabular}{|l|l|l|l|}
\hline \multirow{2}{*}{$\begin{array}{l}\text { Social } \\
\text { Indicator }\end{array}$} & \multicolumn{3}{|l|}{ Obtained Score } \\
\cline { 2 - 4 } & Minimum & Maximum & Average \\
\hline SO1 & 0.492 & 4.921 & 1.513 \\
\hline SO2 & 0.666 & 6.663 & 1.345 \\
\hline SO3 & 0.869 & 5.212 & 1.064 \\
\hline SO4 & 0.389 & 3.894 & 1.548 \\
\hline SO5 & 0.341 & 3.413 & 1.092 \\
\hline SO6 & 0.248 & 2.479 & 2.102 \\
\hline SO7 & 0.200 & 2.004 & 0.870 \\
\hline
\end{tabular}

In the case of social indicators, the availability of governmental services was very few in almost all surveyed areas, and hence this indicated determination of higher vulnerability as shown by an obtained average score of 2.102 in Table 3. According to Dixit et al. (2015), governmental offices provided basic services to local households and communities in normal conditions and make emergency responses during disasters and hence reduced the vulnerability. The situation was opposite in most areas of Panchase and that increased 
vulnerability. The relation between education and vulnerability was agreed to be inversely related (KC, 2013). The higher the education lower would be a vulnerability. The highest education level attended by the family member depicted the overall educational status of the whole family member. The score obtained in the highest educational attainment in Table 3 indicated on average the people have read up to school/secondary level education and this made them moderately vulnerable. On the other hand, the score obtained by indicator, participation in social works showed most people were engaged once or twice a year in social tasks. This also contributed to the moderate vulnerability of the area. The people who were involved in social work are likely to be trusted in a community and could obtain support during times of crisis. It had been observed that the network and trust between the households helped the community to recover from the disaster effects (Madhuri et al., 2014). Effective social participation helps a community to be more resilient or quickly adapt to changing environmental conditions. Other indicators of social factors had much less influence on vulnerability and induced lower vulnerable conditions. The numbers of dependent population (children and old) and people with disabilities in a family were found to be very less and their influence in vulnerability was insignificant.

Table 4: Vulnerability scores obtained for physical indicators

\begin{tabular}{|l|l|l|l|}
\hline \multirow{2}{*}{$\begin{array}{l}\text { Physical } \\
\text { Indicator }\end{array}$} & \multicolumn{3}{|c|}{ Obtained Score } \\
\cline { 2 - 4 } & Minimum & Maximum & Average \\
\hline PY1 & 0.197 & 1.969 & 1.053 \\
\hline PY2 & 0.328 & 3.275 & 1.509 \\
\hline PY3 & 0.185 & 1.852 & 0.766 \\
\hline PY4 & 0.287 & 2.867 & 1.296 \\
\hline PY5 & 0.201 & 2.008 & 0.323 \\
\hline PY6 & 0.314 & 3.136 & 0.993 \\
\hline PY7 & 0.129 & 0.776 & 0.208 \\
\hline
\end{tabular}

In the case of physical factors, indicators like roads, house type, and distance to health-post/hospital obtained average scores, i.e., about half of the weight values derived from AHP as we can see in Table 4, indicating moderate vulnerability. The housing style and road condition can be known from photographs taken during the field survey provided in the Appendix (Figure A1). The condition of the road could determine the efficiency of transportation and quick rehabilitation after landslide incidents (Ebert and Kerle, 2008). For people of Panchase, it took almost one hour or more to reach a nearby health-post or hospital. The earthen road and unavailability of vehicles at timed needed had increased the time of travel in these areas. The health post of the rural area had to be responsible for the medication facilities to the disaster victims. The household nearer to the health post had easy access to the health facilities during the disaster period. The people who were far away from such facilities were more vulnerable. The materials used in household construction 
determined the socio-economic status of the family and provided insights into social vulnerability (Ebert and Kerle, 2008). Most of the houses in Panchase were traditional (stone-mud-wood built) houses and were thought to be increasing the vulnerability of people residing there. The availability of adequate electricity and optimum communication facilities had a lesser influence on vulnerability.

Table 5: Vulnerability scores obtained for economic indicators

\begin{tabular}{|l|l|l|l|}
\hline \multirow{2}{*}{$\begin{array}{c}\text { Economic } \\
\text { Indicator }\end{array}$} & \multicolumn{3}{|c|}{ Obtained Score } \\
\cline { 2 - 4 } EC1 & Minimum & Maximum & Average \\
\hline EC2 & 0.362 & 3.621 & 2.288 \\
\hline EC3 & 0.712 & 7.123 & 5.031 \\
\hline EC4 & 0.520 & 8.593 & 3.396 \\
\hline EC5 & 0.520 & 5.204 & 1.502 \\
\hline EC6 & 0.456 & 5.204 & 2.196 \\
\hline EC7 & 0.824 & 8.237 & 2.288 \\
\hline
\end{tabular}

The results of field data analysis in Table 5 showed that the scores obtained were higher for some of the economic indicators, like availability of banking facilities, insurance facilities, and peoples' savings, reflecting their significant contribution to higher vulnerability. The availability of national banks for financial services and access to loans could be an adaptive measure to the communities during and after hazardous events (Dixit et al., 2015). A score of 2.288 obtained by banking facilities and 5.031 obtained by insurance facilities were relatively higher than scores of other economic indicators as displayed in Table 5. This indicted the insignificant or no availability of such facilities. Banking facilities in Panchase, if available, were only of local scale, mobile banking, and/or temporary ones. The insurances if done can act as a safeguard against crop failure and livestock loss from hazardous activities as the individuals get some financial support (Dixit et al., 2015). Similarly, life and health insurance can secure the probable financial loss of households. The insurance of livestock, life, crops, and health was found to be done in some parts of rural areas of Nepal. Few households of Panchase had done either health insurance or livestock insurance but in most cases the insurance practice was negligible. This can be related to the unavailability of larger financial institutions. Also, people in the Panchase area were reluctant in doing savings for future needs as most of the earnings were spent for daily subsistence. There were few saving groups (women or farmer) where a female member in a family did save some amount of Nepalese Currency (NRs) 200 to 400 per month (1 Dollar of United State equivalent to NRs 120 during the time of research). Higher savings were observed for few people who had permanent jobs in governmental services. Cropping pattern, in terms of number of time the plantations was carried out in a year, showed lower scores revealing that there was crop diversity. The diversity in crops could provide food security and in some case earnings also could contribute to reducing the vulnerability conditions. 
Table 6: Vulnerability scores obtained for environmental indicators

\begin{tabular}{|l|l|l|l|}
\hline Environmental & \multicolumn{3}{|c|}{ Obtained Score } \\
\cline { 2 - 4 } Indicator & Minimum & Maximum & Average \\
\hline EN1 & 0.115 & 1.151 & 0.803 \\
\hline EN2 & 0.126 & 1.257 & 0.382 \\
\hline EN3 & 0.126 & 0.754 & 0.177 \\
\hline EN4 & 0.220 & 2.196 & 1.329 \\
\hline EN5 & 0.942 & 3.139 & 1.788 \\
\hline
\end{tabular}

Similarly, environmental factors like decreased natural sources of water, and reduced numbers of wildlife reflected their influence in higher vulnerability. The households near the water source could have water supply throughout the stress period, even though the pipeline of water supply gets damaged during a landslide. Though there were ponds in most areas, they were dried, seasonal, and used for buffaloes bathing. Also, a lower number of endangered species resembled decreasing diversity in the forest. In most of the areas, the agricultural practice was decreasing and many fallow lands were observed during field visits. This could be a key indicator of increased vulnerability and can make locality insecure about food availability when in need. The score obtained by land use land cover indicator was 0.177, as showed in Table 6 depicted its lower influence in vulnerability. There, were ample forests around the villages. Such dense vegetation reduces surface erosion and decreased the occurrences of landslides making people less vulnerable. Besides, forests provided numerous services for people like wood, fruits, foods, etc.

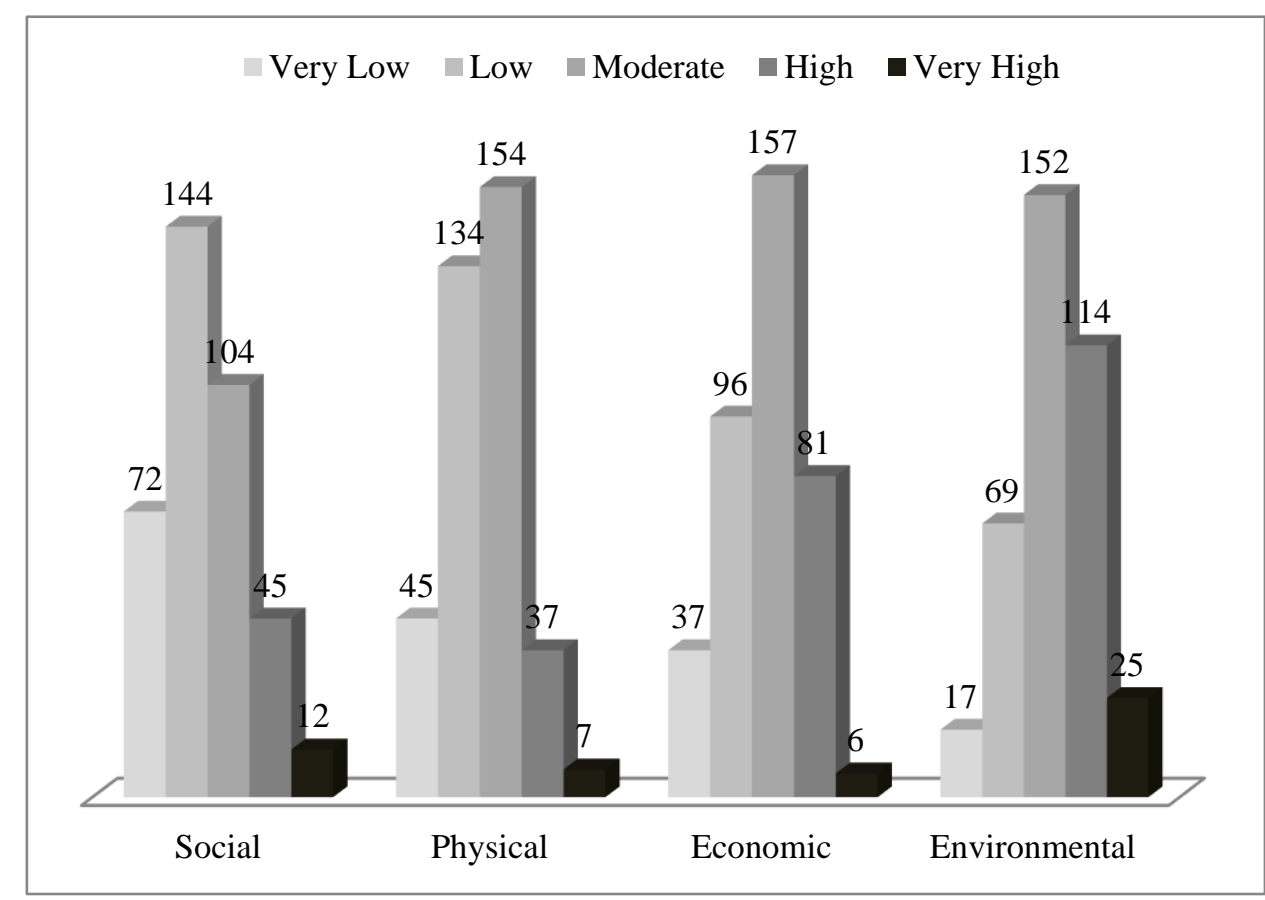

Figure 7: Household distribution based on vulnerability scores of different factors 
The bar diagram in Figure 7 represented the number of households in each of the vulnerability categories for different factors. While observing the social factor, 144 households were under low and 72 were under the very low category of vulnerability. The number of households in these two categories had decreased gradually in physical, economic, and environmental factors. This revealed that the indicators of social factors had their influences on lower vulnerabilities than indicators of other factors. The case was different for moderate vulnerability as a higher number of households were shown in this category under all factors. Now looking at the higher vulnerable category there were 45 households for social factor, 37 households for physical factor, 81 for economic factor, and 114 for the environmental factor. This illustrated the influence of economic and environmental factors in the higher vulnerability of the area. In the case of a very high category of vulnerability, the number of households was 12, 7, 6, and 25 for social, physical, economic, and environmental factors respectively.

So in consideration of whole factors the economic status of households and environmental conditions were found in contributing to the higher vulnerability of the Panchase area. As compared to these two factors social and physical factors had lesser influence in vulnerability. This indicated that social stability and physical development are in good condition in this area.

In researches for risk analysis, it was most important to estimate the vulnerability of peoples who were affected by the hazard incidents and most studies were neglecting this part. This research address this issue by randomly selected households that were closer to landslides within $500 \mathrm{~m}$. Quantification of vulnerability status of peoples or household was one major challenge in similar studies and the method of AHP made the possibility for quantitative analysis of the data. Besides, the applicability of AHP in multi-criteria decisionmaking was also observed as this process utilized numerous indicators to estimate the vulnerability status of an individual unit. This study considered landslide as a hazard for vulnerability estimation. The results would be more significant when considered multi-hazards existing in the area. So, in risk assessments, all prevailing hazards should be considered so that a complete picture of vulnerability can be displayed.

\section{Conclusion}

Thus, the vulnerability was estimated successfully using the AHP process and hence the method can be applied to designate weightage for different factors and their indicators. The vulnerability was observed higher in Galyam and Bage villages of Pedikhola RMP, Odare village of Modi RMP, Tamagi village of PokharaLekhanath MP, Dobila village of Kushma MP. In opposite, the area from Khapaudi village of Pokhara MC 
to Dhikupokhari village of Annapurna RMP lies in a low vulnerable area. Major contributing indicators of vulnerability were observed as availability of fewer governmental services, earthen roads, traditional housing conditions, unavailability of banking and insurance facilities, lower preference to saving the earnings, lower natural sources of water, lower species diversity, and decreasing agriculture trends. The indicators of economic and environmental factors were influencing the high vulnerability in the Panchase area.

\section{Conflict of interest}

The authors declare that there is no conflict of interest.

\section{Authors' contribution}

The research was conceived and designed by Padam Bahadur Budha and Anu Khadka. All authors were involved in data collection and data analysis. Padam Bahadur Budha wrote the paper while others had reviewed it.

\section{Acknowledgments}

We would like to acknowledge the Ministry of Science and Technology, Government of Nepal for providing funds through the Research and Innovative Grants Program 2017-18 that make it possible to conduct this research. We would also like to give our sincere thanks to all the respondents, key informants active, and cordial participation during the questionnaire part of the research.

\section{References}

Aksha, S.K., Juran, L., Resler. L. M., and Zhang, Y., 2019. An analysis of social vulnerability to natural hazards in Nepal using a modified social vulnerability index. International Journal of Disaster Risk Science, 10(1), 103-116. DOI: https://doi.org/10.1007/s13753-018-0192-7

Basnet, P., Balla, M. K., \& Pradhan, and B. M., 2006. Landslide hazard zonation, mapping and investigation of triggering factors in Phewa lake watershed, Nepal. Banko Janakari, 22, 43-52. DOI: https://doi.org/10.3126/banko.v22i2.9198

Bhatt, B. P., Awasthi, K. D., Heyojoo, B. P., Silwal, T., and Kafle, G., 2013. Using Geographic Information System and Analytical Hierarchy Process in Landslide Hazard Zonation. Applied Ecology and Environmental Sciences, 1(2), 14-22. DOI: https://doi.org/10.12691/aees-1-2-1 
Briguglio, L., Cordina, G., Farrugia, N., and Vella, S., 2009. Economic Vulnerability and Resilience: Concepts and Measurements. Oxford Development Studies, 37(3), 229-247. DOI: https://doi.org/10.1080/13600810903089893

Budha, P. B., Paudyal, K., and Ghimire, M., 2020. Indicator based Vulnerability Assessment of ChhayanathRara Municipality, Western Nepal. Environment and Natural Resources Journal, 18(3), 224-223. https://doi.org/10.32526/ennrj.18.3.2020.21

Budha, P. B., Rai P., Katel, P., and Khadka, A., 2020. Landslide hazard mapping in Panchase Mountain of central Nepal. Environment and Natural Resources Journal, 18(4), 387-399. https://doi.org/10.32526/ennrj.18.4.2020.37

Chakraborty, A., and Joshi, P. K., 2016. Mapping disaster vulnerability in India using analytical hierarchy process. Geomatics, Natural Hazards and Risk, 7(1), 308-325. DOI: https://doi.org/10.1080/19475705.2014.897656

Ciurean, R. L., Schröter, D., and Glade, T., 2013. Conceptual Frameworks of Vulnerability Assessments for Natural Disasters Reduction. In J. Tiefenbacher (Ed.), Approaches to Disaster Management Examining the Implications of Hazards, Emergencies and Disasters (pp. 3-32). DOI: https://doi.org/http://dx.doi.org/10.5772/55538 5

Cutter, S. L., Boruff, B. J., and Shirley, W. L., 2003. Social Vulnerability to Environmental Hazards n. Social Science Quarterly, 84(2), 242-261. DOI: https://doi.org/10.1111/1540-6237.8402002

Das, S., and Raja, D. R., 2015. Susceptibility analysis of landslide in Chittagong City corporation area, Bangladesh. International Journal of Environment. 4(2), 157-181. DOI: https://doi.org/10.3126/ije.v4i2.12635

de Brito, M. M., Evers, M., Almoradie, A. D. S., 2018. Participatory flood vulnerability assessment: a multicriteria approach. Hydrology and Earth System Sciences. 22, 373- 390. DOI: https://doi.org/10.5194/hess-22-373-2018

DHM, 2017. Meteorological data of stations in and around Panchase. Department of Hydrology and Meteorology, Government of Nepal

Dixit, A., Karki, M., and Shukla, A., 2015. Vulnerability and Impacts Assessment for Adaptation Planning in Panchase Mountain Ecological Region, Nepal. Kathmandu: Government of Nepal (GoN), United Nations Development Programme (UNDP), International Union for Conservation of Nature (IUCN), German Federal Ministry for the Environment, Nature Conservation, Building and Nuclear Safety (BMUB), and Institute for Social and Environmental Transition-Nepal (ISET-N). https://reliefweb.int/sites/reliefweb.int/files/resources/dixit_et_al_2015_nepal_via_report_panchase_fi nal.pdf (accessed on 12 June 2018). 
Ebert, A., and Kerle, N., 2008. Urban Social Vulnerability Assessment Using Object-Oriented Analysis of Remote Sensing and GIS Data. The International Archives of the Photogrammetry, Remote Sensing and Spatial Information Sciences, 37, 1307-1312. https://www.isprs.org/proceedings/XXXVII/congress/7_pdf/7_WG-VII-7/02.pdf (accessed on 12 February 2018).

Gurung, D. R., Maharjan, S. B., Khanal, N. R., Joshi, G., and Murthy, M. S. R., 2015. Seti Flash Flood: Technical Analysis and DRR Interventions. In R. Dangal, D. Paudel, P. K. Koirala, B. Parajuli, S. B. Thapa, H. D. Shrestha, ... B. P. Kharel (Eds.), Nepal Disaster Report 2015 (pp. 101-110). http://www.drrportal.gov.np/uploads/document/329.pdf (accessed on 21 February 2018)

Guzzetti, F., 2005. Landslide hazard and risk assessment. Doctoral Thesis, 373 pages. University of Bonn, Germany, http://hss.ulb.uni-bonn.de/2006/0817/0817.pdf (accessed on 8 June 2018)

Hahn, M. B., Riederer, A. M., and Foster, S. O., 2009. The Livelihood Vulnerability Index: A pragmatic approach to assessing risks from climate variability and change-A case study in Mozambique. Global Environmental Change, 19(1), 74-88. https://doi.org/10.1016/j.gloenvcha.2008.11.002

KC, S., 2013. Community Vulnerability to Floods and Landslides in Nepal. Ecology and Society 18(1), 8. DOI: https://doi.org/http://dx.doi.org/10.5751/ES-05095-180108

Kayastha, P., Dhital, M. R., and De Smedt, F., 2013. Evaluation and Comparison of GIS based Landslide Susceptibility Mapping Procedures in Kulekhani Watershed, Nepal. Journal Geological Society of India, 81(2), 219-231. DOI: https://doi.org/10.1007/s12594-013-0025-7

Krejcie, R. V, and Morgan, D. W., 1970. Determining Sample Size for Research Activities Robert. Educational and Psychological Measurement, 38(1), 607-610. DOI: https://doi.org/10.1177/001316447003000308

Madhuri, M., Tewari, H. R., and Bhowmick, P. K., 2014. Livelihood vulnerability index analysis: An approach to study vulnerability in the context of Bihar. Jàmbá: Journal of Disaster Risk Studies, 6(1), 1-13. DOI: https://doi.org/10.4102/jamba.v6i1.127

Phuyal, P., Koirala, M., and Dhakal, S., 2015. Comparative Study of Carbon Stock in Different Forest Types of Panchase. In D. R. Bhuju \& K. Rijal (Eds.), Building EbA Knowledge in Nepal (Compilation of EbA Research Studies in Panchase, EbA Pilot Site) (pp. 62-65). Central Department of Environmental Science, Tribhuvan University.

Rezaei, A., and Tahsili S., 2018. Urban Vulnerability Assessment Using AHP. Advances in Civil Engineering. 2018, 1-20. DOI: https://doi.org/10.1155/2018/2018601

Saaty, T. L., 1990. How to make a decision: The Analytic Hierarchy Process. European Journal of Operational Research, 48, 9-26. DOI: https://doi.org/10.1016/0377-2217(90)90057-I 
Saaty, T. L., 2008. Decision making with the analytic hierarchy process. International Journal of Services Sciences, 1(1), 83. DOI: https://doi.org/10.1504/IJSSCI.2008.017590

Sujakhu, N. M., Ranjitkar, S., He, J., Schmidt-Vogt, D., Su, Y., and Xu, J., 2019. Assessing the livelihood vulnerability of rural indigenous households to climate changes in central Nepal, Himalaya. Sustainability, 11(10), 2977. DOI: https://doi.org/10.3390/su11102977

Tesso, G., Emana, B., and Ketema, M., 2012. Analysis of vulnerability and resilience to climate change induced shocks in North Shewa, Ethiopia. Agricultural Sciences, 3(6), 871-888. DOI: https://doi.org/10.4236/as.2012.36106

Yue, J., and Zhang, K., 2014. Vulnerability Threat Assessment Based on AHP And Fuzzy Comprehensive Evaluation. Seventh International Symposium on Computational Intelligence and Design. IEEE Computer Society. 513-516. DOI: https://doi.org/10.1109/ISCID.2014.231

\section{Appendix}

Table A1: AHP contingency table for estimation weight of factors.

\begin{tabular}{|l|l|l|l|l|l|l|}
\hline Factors & Social & Physical & Economic & Environmental & Weight & \% Weight \\
\hline Social & 1.00 & 3.00 & 0.50 & 4.00 & 0.32 & 32.06 \\
\hline Physical & 0.33 & 1.00 & 0.33 & 3.00 & 0.16 & 16.40 \\
\hline Economic & 2.00 & 3.00 & 1.00 & 3.00 & 0.43 & 42.54 \\
\hline Environmental & 0.25 & 0.33 & 0.33 & 1.00 & 0.09 & 9.00 \\
\hline Total & 3.58 & 7.33 & 2.17 & 11.00 & & 100.00 \\
\hline & Eigen Vector $=4.26$ & & CR $=0.097$ & & \\
\hline
\end{tabular}

Table A2: AHP contingency table for estimation weight of indicators.

\begin{tabular}{|l|l|l|l|l|l|l|l|l|l|}
\hline Social & SO1 & SO2 & SO3 & SO4 & SO5 & SO6 & SO7 & Weight & $\%$ Weight \\
\hline SO1 & 1 & 0.5 & 0.5 & 2 & 2 & 2 & 2 & 0.15 & 4.92 \\
\hline SO2 & 2 & 1 & 0.5 & 2 & 2 & 3 & 3 & 0.21 & 6.66 \\
\hline SO3 & 2 & 2 & 1 & 3 & 2 & 3 & 3 & 0.27 & 8.69 \\
\hline SO4 & 0.5 & 0.5 & 0.33 & 1 & 2 & 2 & 2 & 0.12 & 3.89 \\
\hline SO5 & 0.5 & 0.5 & 0.5 & 0.5 & 1 & 2 & 2 & 0.11 & 3.41 \\
\hline SO6 & 0.5 & 0.33 & 0.33 & 0.5 & 0.5 & 1 & 2 & 0.08 & 2.48 \\
\hline SO7 & 0.5 & 0.33 & 0.33 & 0.5 & 0.5 & 0.5 & 1 & 0.06 & 2.00 \\
\hline & 7 & 5.17 & 3.5 & 9.5 & 10 & 13.5 & 15 & & 32.06 \\
\hline & Eigen & Vector & 7.296 & & CR & 0.037 & & & \\
\hline Physical & PY1 & PY2 & PY3 & PY4 & PY5 & PY6 & PY7 & Weight & $\%$ Weight \\
\hline PY1 & 1 & 0.5 & 2 & 0.5 & 1 & 0.5 & 2 & 0.12 & 1.97 \\
\hline PY2 & 2 & 1 & 2 & 2 & 2 & 0.5 & 2 & 0.20 & 3.28 \\
\hline PY3 & 0.5 & 0.5 & 1 & 0.5 & 2 & 0.5 & 2 & 0.11 & 1.85 \\
\hline PY4 & 2 & 0.5 & 2 & 1 & 2 & 1 & 2 & 0.17 & 2.87 \\
\hline PY5 & 1 & 0.5 & 0.5 & 0.5 & 1 & 2 & 1 & 0.12 & 2.01 \\
\hline PY6 & 2 & 2 & 2 & 1 & 0.5 & 1 & 2 & 0.19 & 3.14 \\
\hline
\end{tabular}




\begin{tabular}{|c|c|c|c|c|c|c|c|c|c|}
\hline \multirow[t]{3}{*}{ PY7 } & 0.5 & 0.5 & 0.5 & 0.5 & 1 & 0.5 & 1 & \multirow[t]{2}{*}{0.08} & 1.29 \\
\hline & 9 & 5.5 & 10 & 6 & 9.5 & 6 & 12 & & 16.4 \\
\hline & \multicolumn{4}{|c|}{ Eigen Vector $=7.614$} & \multicolumn{3}{|c|}{$\mathrm{CR}=0.077$} & & \\
\hline Economic & EC1 & $\mathrm{EC} 2$ & EC3 & EC4 & EC5 & EC6 & EC7 & Weight & $\%$ Weight \\
\hline EC1 & 1 & 1 & 0.5 & 0.5 & 0.5 & 0.5 & 0.5 & 0.09 & 3.62 \\
\hline $\mathrm{EC} 2$ & 1 & 1 & 0.5 & 2 & 2 & 2 & 1 & 0.17 & 7.12 \\
\hline EC3 & 2 & 2 & 1 & 2 & 2 & 1 & 1 & 0.20 & 8.59 \\
\hline EC4 & 2 & 0.5 & 0.5 & 1 & 1 & 2 & 0.5 & 0.12 & 5.20 \\
\hline EC5 & 2 & 0.5 & 0.5 & 1 & 1 & 2 & 0.5 & 0.12 & 5.20 \\
\hline EC6 & 2 & 0.5 & 1 & 0.5 & 0.5 & 1 & 0.5 & 0.11 & 4.56 \\
\hline EC7 & 2 & 1 & 1 & 2 & 2 & 2 & 1 & 0.19 & 8.24 \\
\hline Total & 12 & 6.5 & 5 & 9 & \multirow{2}{*}{\multicolumn{3}{|c|}{$\begin{array}{ll}9 & 10.5 \\
\mathrm{CR}=0.052\end{array}$}} & & 42.54 \\
\hline & Eige & Vector & $=7.415$ & & & & & & \\
\hline \multicolumn{2}{|c|}{ Environmental } & EN1 & EN2 & \multicolumn{2}{|c|}{ EN3 } & EN4 & EN5 & Weight & $\%$ Weight \\
\hline \multicolumn{2}{|l|}{ EN1 } & 1 & 1 & \multicolumn{2}{|l|}{1} & 0.5 & 0.33 & 0.13 & 1.15 \\
\hline \multicolumn{2}{|l|}{ EN2 } & 1 & 1 & \multicolumn{2}{|c|}{1} & 0.5 & 0.5 & 0.14 & 1.26 \\
\hline \multicolumn{2}{|l|}{ EN3 } & 1 & 1 & 1 & & 0.5 & 0.5 & 0.14 & 1.26 \\
\hline EN4 & & 2 & 2 & 2 & & 1 & 0.5 & 0.24 & 2.20 \\
\hline EN5 & & 3 & 2 & 2 & & 2 & 1 & 0.35 & 3.14 \\
\hline Total & & 8 & 7 & 7 & & 4.5 & 2.83 & & 9 \\
\hline & & Eige & Vecto & $=50.65$ & & $\mathrm{CR}=0$. & & & \\
\hline
\end{tabular}

Table A3: Response categories for each indicator in the questionnaire developed.

\begin{tabular}{|c|c|c|c|c|}
\hline \multirow[t]{2}{*}{ Indicator } & \multicolumn{4}{|c|}{ Response Categories } \\
\hline & A & $\mathrm{B}$ & $\mathrm{C}$ & $\mathrm{D}$ \\
\hline Family size & $<2$ & $>10$ & 3 to5 & 6 to 9 \\
\hline Dependent age group & $>7$ & 5 to6 & 3 to 4 & $<2$ \\
\hline People with disabilities & $>3$ & 2 & 1 & 0 \\
\hline Highest education & below 5 & SLC & $10+2$ & Bachelor \\
\hline Participation in social works & none & once/year & once/quarterly & once/month \\
\hline Governmental Services & $<2$ & $3-4$ & $5-6$ & $>7$ \\
\hline Non-governmental services & none & once & twice & frequently \\
\hline Roads types & trail & earthen & graveled & blacktopped \\
\hline Building types & temporary & traditional & mixed & concrete \\
\hline School-level & none & elementary & secondary & college \\
\hline Distance to the health post & 2 hour & 1 hour & $30 \mathrm{~min}$ & $15 \mathrm{~min}$ \\
\hline Electricity sources & none & micro hydro & solar & large hydro \\
\hline Water supply & none & piping & pipe+dam & $\begin{array}{l}\text { pipe/dam/user } \\
\text { group }\end{array}$ \\
\hline Communication facilities & none & radio/TV & telephone & mobile/internet \\
\hline Banking facilities & none & cooperative & regional & national \\
\hline Insurance facilities & none & health & life & life+assets \\
\hline Employment options & unemployed & Agriculture & Agri. + business & non agriculture \\
\hline Cropping pattern & none & 1 & 2 & 3 \\
\hline Livestock diversity & none & 1 & 2 & 3 \\
\hline
\end{tabular}




\begin{tabular}{|l|l|l|l|l|}
\hline Monthly expenditure & low & $\begin{array}{l}\text { below } \\
\text { average }\end{array}$ & average & above average \\
\hline Savings & none & $\begin{array}{l}\text { below } \\
\text { average }\end{array}$ & average & above average \\
\hline Lakes and Ponds & 0 & 1 & 2 & 3 \\
\hline Protected Forest & unprotected & private & community & Protected areas \\
\hline Land use land cover & barren & grass & bushy & Dense forest \\
\hline Faunal diversity & rare & decreasing & constant & increasing \\
\hline Agricultural Lands & barren & decreasing & constant & increasing \\
\hline
\end{tabular}
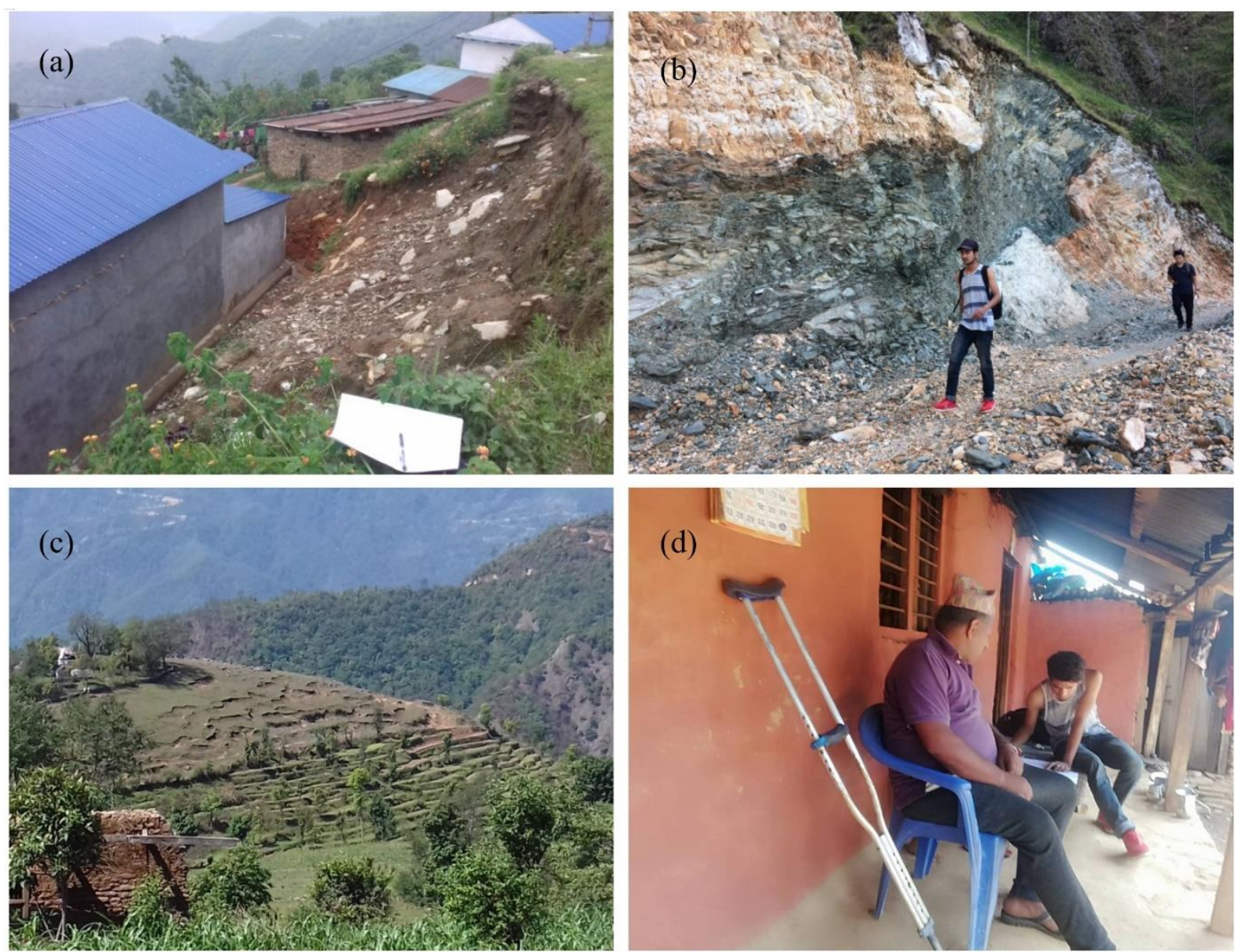

Figure A1: (a) House reconstructed after shallow landslide at Eklakhet village of Pokhara-18 (b) Different rock and high weathering the way to Galyam village from Aarukharka, Phedikhola-4 (c) Landslide cracks observed at Bage village of Phedikhola-5, (d) Questionnaire survey at Pumdi village of Pokhara-22. 